\title{
Characteristics and Skills Necessary in Accountancy
}

\author{
Susan C. O’Shea ${ }^{1}$ \\ ${ }^{1}$ University College Cork, Cork, Ireland \\ Correspondence: Susan C. O'Shea, MCW, Rathmore House, South Douglas Road, Cork, Ireland. E-mail: \\ susanoshea2017@gmail.com
}

Received: October 15, 2017

Accepted: November 18, 2017

Online Published: December 20, 2017

doi:10.5539/ijbm.v13n1p22

URL: https://doi.org/10.5539/ijbm.v13n1p22

\begin{abstract}
The recruitment of accountants poses challenges for accountancy firms. Person-job fit affects success and influences the likelihood of remaining with a firm. With expected growth in the industry addressing these challenges is essential.

This research aimed to determine the characteristics and skills necessary for accountancy and whether current students exhibit these qualities. It was based on Holland's RIASEC model and characteristics of interest in accountancy including analytical skill, preference for structure, communication and interpersonal skills, risk approach and conscientiousness. Experts in accountancy were interviewed to determine the desired characteristics for the profession. Accountancy students were then surveyed to measure their skills.

Communication skills and enterprising characteristics were the most valued qualities of accountants. Students had a preference for structure and a cautious approach to risk. They had some of the characteristics considered useful in accountancy including conventional and investigative characteristics and conscientiousness. Desirable characteristics varied for different specialisations. While students with specialisation preferences had specific characteristics, these rarely matched those required. Exceptions were preferences for forensic accountancy and tax.

This research makes a theoretical contribution to the application of the RIASEC model to accountancy, suggesting a modification of the pre-existing classifications. Practical implications also arise for employers, students and educators.
\end{abstract}

Keywords: accountants, characteristics, communication and interpersonal skills, enterprising characteristics, recruitment, RIASEC

\section{Introduction}

Accountancy firms invest substantially in training new recruits and frequently report dissatisfaction that accountants are increasingly leaving to work in industry upon professional qualification. Poor person-job fit has been acknowledged to be a factor in turnover (Pholphirul, 2017). A contributing factor to poor person-job fit in accountancy may be the stereotypical image of accountants described by Chen, Jones, Scarlata and Stone (2012). This may result in individuals with a poor fit for the role of accountant being attracted into the profession. While employers have been found to consider person-organisation fit (Jackling \& Watty, 2010), their lack of attention to the suitability of the candidate for the role itself is likely to affect turnover rates. In order to encourage retention of accountants, careful consideration needs to be given to their characteristics at the recruitment stage (Levy et al., 2011). This would assist in the development of an employee base to service the expected growth in the industry (Chartered Accountants of Ireland, 2016).

In addition to being of value to employers in terms of person-job fit, this research has important implications for students and educators. There is a need for students to have a greater understanding of their characteristics and their suitability for accounting specialisations. Addressing this issue benefits students in their career decisions. Similarly, there is a need to improve the development of skills through education.

It has been acknowledged that teaching at university should include skills training in addition to technical instruction (Siriwardane, Hu \& Low, 2014). While efforts have been made to incorporate the teaching of critical thinking, interpersonal skills, communication and leadership skills, previous studies have found that the training of these skills at university is not adequate from the employers' perspective (Bloch, Brewer \& Stout, 2012; 
Gupta \& Marshall, 2010; Jackling \& De Lange, 2009; Kavanagh \& Drennan, 2008; Siriwardane et al., 2014). This may be due to a disparity between educators and employers in terms of their opinion of what is necessary in the profession (Crawford, Helliar \& Monk, 2011). Improvements to the curriculum to address these skills gaps may best be made over time (Lawson et al., 2015).

\section{Characteristics and Skills Considered in the Research}

This research considered characteristics and skills valued in accountancy. Holland's (1959) RIASEC model was the framework upon which this research was built. Holland categorised individuals according to their vocational characteristics using six dimensions. These are realistic, investigative, artistic, social, enterprising and conventional. Realistic types are practical and are considered to be down to earth. Investigative types are intellectual, curious and enjoy solving problems. Those with an artistic disposition tend to be creative and expressive. Social types are empathetic and helpful. Enterprising types are described as ambitious, extraverted and optimistic. Conventional types are orderly and they like to follow the rules.

Holland's 'self-directed search' (1973) categorised individuals into three RIASEC classifications. Accountants were considered to be primarily conventional followed by enterprising and social. Later revisions exchanged social for investigative (Gottfredson \& Holland, 1996). Recent research involving RIASEC classifications of accountants has generally agreed with conventional as the primary classification. Secondary classifications have been described as investigative or enterprising and tertiary classifications as social or realistic (Chen et al., 2012). Interestingly, Silva, Portela, Santos and Taveira (2014) describe enterprising as the primary classification for accountants. They define the secondary classification as social or conventional and the tertiary classification as social, conventional or investigative.

Additional characteristics and skills considered in this research include analytical skills, having a preference for structure, communication and interpersonal skills, risk approach and conscientiousness.

\subsection{Research Objectives}

The existing accounting literature suggests that trainee accountants require considerable on-the-job training to be assets to the firm (Kavanagh \& Drennan, 2008). An aim of this research was to determine the characteristics and skills of importance for a career in accountancy and specifically for its specialisations. It was deemed useful to determine the characteristics of current accountancy students. Previous research indicated that certain characteristics are useful for different specialisations. Therefore, it was hypothesised that accountancy students' specialisation preferences may relate to their vocational characteristics. It was considered useful to investigate whether the students' characteristics were, in fact, related to their preferences. Finally, this research aimed to determine whether gaps exist between the characteristics of the students and those valued in accountancy and its' specialisations.

\section{Method}

A mixed methods approach was taken with this research.

\subsection{Participants}

This research involved interviews with eight accountancy experts and a survey of 59 accountancy students. The experts comprised professional accountants, accountancy lecturers and a recruiter of accountants. The students were recruited from accountancy courses at two Irish colleges, University College Cork and Cork Institute of Technology.

\subsection{Expert Interviews}

A semi-structured interview questionnaire was developed and employed in the expert interviews. Having been introduced to the nature and purpose of the study, the experts were asked to describe their work experience in the industry. They were then asked questions aimed to determine the characteristics and skills considered valuable for accountants at different stages of their careers and for promotion. The experts' opinion was sought on which characteristics are valuable for different specialisations and whether any of the characteristics would hinder accountants. These questions were based on the RIASEC model and conscientiousness. The experts' view of the relevance of this model to accountancy and whether different characteristics are sector dependent was also probed.

\subsubsection{Sampling Scheme and Data Collection}

Experts in accountancy were recruited using purposeful sampling based on their experience, as recommended by Sandelowski (2000). All had experience of working as accountants and had been involved in hiring. Having received introductory materials relating to the research prior to the meetings, the experts were interviewed. When 
interviews ceased to yield new information, data collection ended, as recommended by Cleary, Horsfall and Hayter (2014). Subsequent to transcription and anonymisation, the information was analysed.

\subsubsection{Analysis Approach}

Thematic analysis included familiarisation with the data (Braun \& Clarke, 2006), memoing, note taking and code development (Tuckett, 2005). Systematic coding and categorisation into themes resulted in a detailed analysis of the data. Information relating to RIASEC dimensions and conscientiousness for the specialisations was collated to determine the areas of agreement amongst the experts.

\subsection{Student Survey}

A student survey was prepared by developing scales to measure the characteristics of interest for accountancy. This was made available to the students via the online platform Survey Monkey. The measures considered were expanded beyond the RIASEC dimensions and were informed by the expert interviews. In addition to items relating to the measures, students were also asked to indicate their top three specialisation preferences from a choice of audit, forensic, public, tax, enterprise, consultancy and financial advice. Preferences for working in a family firm or a large accountancy firm were also considered (Bishop, 2017). The expert interviews contributed to the addition of enterprise and working in a large accountancy firm to the choice of preferences.

\subsubsection{Measures}

Table 1. Scale items for each measure and their source

\begin{tabular}{|c|c|c|}
\hline Measure & Scale item & Source \\
\hline \multirow[t]{6}{*}{ Realistic } & I enjoy exercise & International Personality Item Pool (2017) \\
\hline & I purchase only practical things & International Personality Item Pool (2017) \\
\hline & I think up practical solutions & International Personality Item Pool (2017) \\
\hline & I am told that I am down to earth & International Personality Item Pool (2017) \\
\hline & I am fascinated by how machines work & International Personality Item Pool (2017) \\
\hline & I am interested in science & International Personality Item Pool (2017) \\
\hline \multirow[t]{5}{*}{ Investigative } & I am good at analysing problems & International Personality Item Pool (2017) \\
\hline & I am one of the most curious people I know & International Personality Item Pool (2017) \\
\hline & I like to ask questions that nobody else does & International Personality Item Pool (2017) \\
\hline & I can come up with alternative options & International Personality Item Pool (2017) \\
\hline & I seek explanations of things & International Personality Item Pool (2017) \\
\hline \multirow[t]{6}{*}{ Artistic } & I am considered to be eccentric & International Personality Item Pool (2017) \\
\hline & I am interested in abstract ideas & International Personality Item Pool (2017) \\
\hline & I notice small visual details & International Personality Item Pool (2017) \\
\hline & I am aware of natural beauty in the environment & International Personality Item Pool (2017) \\
\hline & $\begin{array}{l}\text { I am aware how colour and lighting affect my } \\
\text { mood }\end{array}$ & International Personality Item Pool (2017) \\
\hline & I see the beauty in everyday things & International Personality Item Pool (2017) \\
\hline \multirow[t]{6}{*}{ Social } & I am interested in people & International Personality Item Pool (2017) \\
\hline & I am never too busy to help a friend & International Personality Item Pool (2017) \\
\hline & I am a sympathetic person & International Personality Item Pool (2017) \\
\hline & $\begin{array}{l}\text { I am often consulted by my friends about their } \\
\text { problems }\end{array}$ & International Personality Item Pool (2017) \\
\hline & I feel saddened by the suffering of others & International Personality Item Pool (2017) \\
\hline & I offer to help with people's problems & International Personality Item Pool (2017) \\
\hline \multirow[t]{6}{*}{ Enterprising } & I am good at taking charge of a group & International Personality Item Pool (2017) \\
\hline & My friends would say that I like to take risks & International Personality Item Pool (2017) \\
\hline & I get excited by new ideas & International Personality Item Pool (2017) \\
\hline & I am able to do most things well & International Personality Item Pool (2017) \\
\hline & I am able to see the best in a situation & International Personality Item Pool (2017) \\
\hline & I am always looking for a rush of excitement & International Personality Item Pool (2017) \\
\hline \multirow[t]{3}{*}{ Conventional } & I like to complete my work on time & International Personality Item Pool (2017) \\
\hline & I like to be organised & International Personality Item Pool (2017) \\
\hline & I act properly in most situations & International Personality Item Pool (2017) \\
\hline
\end{tabular}




\begin{tabular}{|c|c|c|}
\hline & I deal efficiently with practical matters & International Personality Item Pool (2017) \\
\hline \multirow[t]{3}{*}{ Analytical } & I enjoy trying to solve complex problems & Amabile, Hill, Hennessey and Tighe (1994) \\
\hline & I have the skills to find and assess information & Amabile, Hill, Hennessey and Tighe (1994) \\
\hline & $\begin{array}{l}\text { I have the ability to make my own conclusions } \\
\text { based on what I am evaluating }\end{array}$ & Amabile, Hill, Hennessey and Tighe (1994) \\
\hline \multirow[t]{2}{*}{ Structure } & $\begin{array}{l}\text { I prefer working on projects with clearly specified } \\
\text { procedures }\end{array}$ & Amabile, Hill, Hennessey and Tighe (1994) \\
\hline & $\begin{array}{l}\text { I prefer having someone set clear goals for me in } \\
\text { my work }\end{array}$ & Amabile, Hill, Hennessey and Tighe (1994) \\
\hline \multirow[t]{10}{*}{ Communication } & $\begin{array}{l}\text { I share information generally rather than keeping it } \\
\text { to myself }\end{array}$ & Anderson and West (1998) \\
\hline & $\begin{array}{l}\text { I co-operate with others in order to help develop } \\
\text { and apply new ideas }\end{array}$ & Anderson and West (1998) \\
\hline & $\begin{array}{l}\text { I provide and share resources to help in the } \\
\text { application of new ideas }\end{array}$ & Anderson and West (1998) \\
\hline & I keep in touch with others in the class & Anderson and West (1998) \\
\hline & $\begin{array}{l}\text { I meet frequently with my classmates to talk both } \\
\text { formally and informally }\end{array}$ & Anderson and West (1998) \\
\hline & I interact frequently with others in our class & Anderson and West (1998) \\
\hline & $\begin{array}{l}\text { I have a reputation for being able to cope with } \\
\text { difficult people }\end{array}$ & Holland and Baird (1968) \\
\hline & I find it easy to talk with all kinds of people & Holland and Baird (1968) \\
\hline & $\begin{array}{l}\text { I have unusual skills for making groups, clubs or } \\
\text { organisations function effectively }\end{array}$ & Holland and Baird (1968) \\
\hline & If I want to, I can be a very persuasive person & Holland and Baird (1968) \\
\hline \multirow[t]{5}{*}{ Risk (strategy) } & Gather more information & Helliar, Lonie, Power and Sinclair (2002) \\
\hline & Consult with colleagues & Helliar, Lonie, Power and Sinclair (2002) \\
\hline & Consult experts & Helliar, Lonie, Power and Sinclair (2002) \\
\hline & $\begin{array}{l}\text { Consider the differences between this decision and } \\
\text { earlier ones }\end{array}$ & Helliar, Lonie, Power and Sinclair (2002) \\
\hline & $\begin{array}{l}\text { Consider the similarities between this decision and } \\
\text { earlier decisions }\end{array}$ & Helliar, Lonie, Power and Sinclair (2002) \\
\hline \multirow[t]{2}{*}{ Risk (attitude) } & I prefer to avoid risks & Meertens and Lion (2008) \\
\hline & I usually view risks as a challenge & Meertens and Lion (2008) \\
\hline \multirow[t]{5}{*}{ Conscientiousness } & I like to keep my room neat and tidy & International Personality Item Pool (2017) \\
\hline & I am a perfectionist & International Personality Item Pool (2017) \\
\hline & I am a hard worker & International Personality Item Pool (2017) \\
\hline & I like to weigh the pros and cons & International Personality Item Pool (2017) \\
\hline & I am a firm believer in thinking things through & International Personality Item Pool (2017) \\
\hline
\end{tabular}

Table 1 describes the items used in the scales for each measure. The items were specifically selected from published materials relating to the personality dimensions of interest in the study and in many cases also to the personality of accountants. This ensured that the items were appropriate for each measure.

Realistic characteristics were measured using a six item scale developed using the International Personality Item Pool (2017). An example item is 'I am told that I am down to earth'. Students responded on a five point Likert scale ranging from 1 , strongly disagree, to 5 , strongly agree ( $\alpha=0.68, M=3.42, S D=0.67$ ).

Investigative characteristics were measured using five items from the International Personality Item Pool (2017). An example item is 'I am one of the most curious people I know'. Students responded on a five point Likert scale ranging from 1 , strongly disagree, to 5 , strongly agree $(\alpha=0.72, M=3.73, S D=0.56)$.

Six items from the International Personality Item Pool (2017) were used to measure artistic characteristics. An example item is ' $I$ am interested in abstract ideas'. Responses were made on a five point Likert scale ranging from 1 , strongly disagree, to 5 , strongly agree $(\alpha=0.8, M=3.38, S D=0.77)$.

Social characteristics were measured using six items from the International Personality Item Pool (2017). An example item is 'I am never too busy to help a friend'. Responses were made on a five point Likert scale ranging 
from 1 , strongly disagree, to 5 , strongly agree ( $\alpha=0.83, M=4.06, S D=0.60)$.

Enterprising characteristics were measured using six items from the International Personality Item Pool (2017). An example item is 'I am good at taking charge of a group'. Students responded on a five point Likert scale ranging from 1 , strongly disagree, to 5 , strongly agree $(\alpha=0.77, M=3.51, S D=0.69)$. One missing value was replaced with the mean of the scale as recommended by Downey and King (1998).

Four items from the International Personality Item Pool (2017) were used to measure conventional characteristics. The scale originally had six items. Following data preparation the Cronbach's alpha was assessed. Values $>0.7$ indicate that a scale is reliable (Bland \& Altman, 1997). By deleting two items it was possible to improve the reliability of the scale to $>0.7$. An example of an item which was used is 'I like to complete my work on time'. Students responded on a five point Likert scale ranging from 1, strongly disagree, to 5 , strongly agree $(\alpha=0.54, M=4.10, S D=0.50)$. One missing value was replaced.

Analytical skills were measured using three items from the work preference inventory (Amabile, Hill, Hennessey $\&$ Tighe, 1994). An example item is 'I enjoy trying to solve complex problems'. Students responded on a five point Likert scale ranging from 1 , strongly disagree, to 5 , strongly agree $(\alpha=0.58, M=3.99, S D=0.55)$.

Preference for structure was measured using two items from the work preference inventory (Amabile et al., 1994). Originally this scale had three items. However, following data preparation the Cronbach's alpha was assessed and the scale was reduced to two items to improve the reliability (Bland \& Altman, 1997). An example of an item used in the scale is 'I prefer working on projects with clearly specified procedures'. Students responded on a five point Likert scale ranging from 1 , strongly disagree, to 5 , strongly agree ( $\alpha=0.57, M=4.18$, $S D=0.66$ ).

Ten items were used to measure the students' communication and interpersonal skills. These were sourced from the team climate inventory (Anderson \& West, 1998) and the interpersonal competency scale (Holland \& Baird, 1968). An example item is 'If I want to I can be a very persuasive person'. Students responded on a five point Likert scale ranging from 1 , strongly disagree, to 5 , strongly agree $(\alpha=0.79, M=3.48, S D=0.59)$. One missing value was replaced.

Risk approach was measured using nine items. Two of these were dilemma-based questions, sourced from published research (Helliar, Lonie, Power \& Sinclair, 2002). Two items were sourced from the risk propensity scale (Meertens \& Lion, 2008). The remaining five items were sourced from published research aimed to measure risk approach (Helliar et al., 2002). Students were asked to indicate how likely they would be to adopt different strategies to control risks. An example item is 'Gather more information'. Responses were made on a five point Likert scale ranging from 1 , strongly disagree, to 5 , strongly agree $(\alpha=0.72, M=4.12, S D=0.51)$. Nine missing values were replaced, representing $15 \%$ of respondents, which is considered acceptable (Downey \& King, 1998).

Five items were used to measure conscientiousness and were sourced from the International Personality Item Pool (2007). An example item is 'I am a hard worker'. Students were asked to respond to five of the items on a five point Likert scale ranging from 1 , strongly disagree, to 5 , strongly agree $(\alpha=0.55, M=3.95, S D=0.57)$. Four missing values were replaced. An open question about their reason for choosing accountancy was also included.

Demographic information was collected relating to age, gender, the college attended, the degree course the students are registered for and any prior experience in accountancy. The students' ages were analysed and the mode of the responses was calculated. The most common age was found to be 21 years old $(S D=5.82)$. Students were also asked to indicate their top three specialisation preferences from a choice of audit, forensic, public, tax, enterprise, consultancy, financial advice, family firm and large accountancy firm.

\subsubsection{Analysis methods}

The mean of each scale was calculated to determine the characteristics of the students. Differences in student characteristics depending on specialisation preferences were determined using independent-samples t-tests. Analysis of covariance replaced t-tests in cases where age and gender influenced results. Subsequent to checking assumptions, the significance of the tests was assessed. The partial eta squared was calculated and interpreted according to Cohen's (1988) guidelines.

\section{Results}

The results of the expert interviews, student survey and a comparison of both are presented. 


\subsection{Expert Interview Results}

Thematic analysis of the interview transcripts indicated that the experts valued certain characteristics. These characteristics were not suggested to the experts as part of the interview, rather, they emerged as recurring themes upon analysis of the transcripts. The interview transcripts were also examined in relation to RIASEC dimensions and conscientiousness in line with the aims of the study. Overall, the characteristics most valued by the experts were communication skills and enterprising characteristics. Conventional and investigative characteristics and conscientiousness were also of importance. Realistic characteristics, a preference for structure, analytical skills and approach to risk were less important. While artistic characteristics were somewhat useful, social characteristics were not valued.

The experts concurred that different characteristics are useful depending on the specialisation. Experts were specifically questioned as to their opinion of the importance of the RIASEC dimensions and conscientiousness for the different specialisations as per the study aims. Realistic characteristics were considered important for audit, forensic accountancy, consultancy and working in a family firm. Investigative characteristics were valued for audit and tax. Artistic characteristics were considered useful for consultancy. Enterprising characteristics were considered important for consultancy, financial advisory work and working in family firms. Conventional characteristics were found to be valuable for audit, forensic accountancy, financial advisory work and family firms. Conscientiousness was considered important for audit, forensic accountancy and tax. As the study was sequential qualitative-quantitative in nature, subsequent findings of the interviews such as the importance of communication skills and enterprising characteristics did not form part of the questionnaire with regard to specialisations.

\subsection{Student Survey Results}

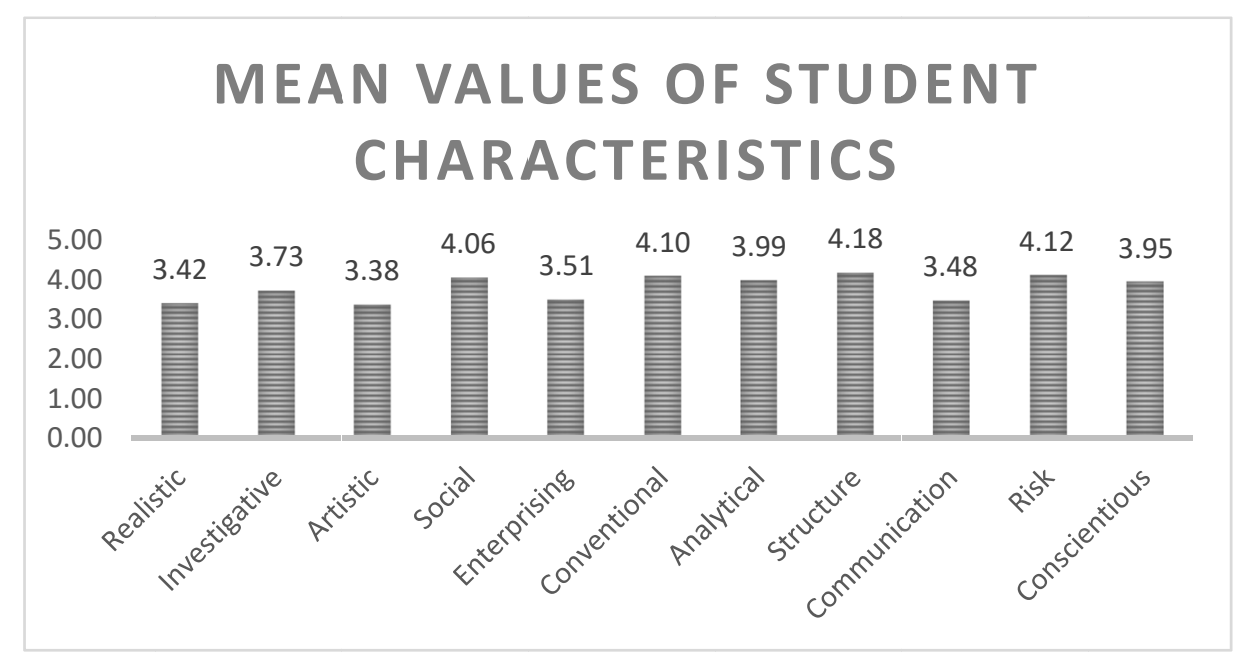

Figure 1. Mean values of student characteristics

The results of the student survey indicate that some characteristics were more dominant than others in the student sample (Figure 1). A preference for structure, a cautious approach to risk, conventional and social characteristics were among the most dominant characteristics. Artistic and realistic characteristics and communication skills were among the least dominant characteristics and skills.

Table 2. Significant independent-samples t-test results

\begin{tabular}{|c|c|c|c|c|c|c|c|c|c|}
\hline \multirow[t]{2}{*}{ Measure } & \multirow{2}{*}{$\begin{array}{l}\text { Specialisation } \\
\text { preference }\end{array}$} & \multirow[t]{2}{*}{$t(57)$} & \multicolumn{3}{|c|}{ Yes } & \multicolumn{3}{|c|}{ Nio } & \multirow{2}{*}{$\begin{array}{l}\text { Partial eta } \\
\text { squared }\end{array}$} \\
\hline & & & $n$ & $M$ & $S D$ & $n$ & M & $S D$ & \\
\hline Realistic & Enterprise & 2.03 & 12 & 3.76 & .64 & 47 & 3.33 & .66 & .07 \\
\hline Conventional & Financial advice & -2.92 & 17 & 3.82 & .47 & 42 & 4.22 & .47 & .13 \\
\hline Analytical & Forensic & 3.05 & 14 & 4.36 & .59 & 45 & 3.87 & .49 & .14 \\
\hline Structure & Family firm & 2.11 & 8 & 4.63 & .44 & 51 & 4.11 & .67 & .07 \\
\hline Structure & Financial advice & -2.26 & 17 & 3.88 & .74 & 42 & 4.30 & .60 & .08 \\
\hline Risk & Audit & -2.05 & 23 & 3.97 & .49 & 36 & 4.22 & .44 & .07 \\
\hline
\end{tabular}


Table 3. Significant ANCOVA results

\begin{tabular}{|c|c|c|c|c|c|c|c|}
\hline Measure & & Specialisation preference & & Test value & $p$ & $\begin{array}{l}\text { Partial eta } \\
\text { squared }\end{array}$ & $\begin{array}{l}\text { Controlled } \\
\text { variable }\end{array}$ \\
\hline Investigative & & Tax & $F(1,45)$ & 4.62 & .04 & .09 & Age \\
\hline $\begin{array}{l}\text { Conscientiousness } \\
\text { students) }\end{array}$ & (CIT & Forensic & $F(1,21)$ & 8.72 & .01 & .29 & Gender \\
\hline
\end{tabular}

Independent-samples t-tests (Table 2) and analysis of covariance results (Table 3) indicate that student characteristics varied by specialisation preference. Key findings were that students with a preference for audit had a less cautious approach to risk. Those interested in forensic accounting were analytical. Cork Institute of Technology students with a preference for forensic accounting had higher conscientiousness scores than those without this preference. Students with an interest in tax were investigative. Those with a preference for enterprise were realistic but interestingly not enterprising. Students who were interested in financial advice were less conventional and had lower preference for structure scores. Those with an interest in working in a family firm liked structure.

\subsection{Comparison of Student Characteristics with Those Valued in Accountancy}

Table 4. Comparison of accountancy students' characteristics and those valued by the experts

\begin{tabular}{|c|c|c|c|}
\hline \multicolumn{2}{|l|}{ Students } & \multicolumn{2}{|l|}{ Experts } \\
\hline Rating & Characteristic & Rating & Characteristic \\
\hline \multirow[t]{4}{*}{ Dominant } & Structure & Highly valued & Communication \\
\hline & Risk & & Enterprising \\
\hline & Conventional & & \\
\hline & Social & & \\
\hline \multirow[t]{3}{*}{ Moderately dominant } & Analytical & Moderately valued & Conventional \\
\hline & Conscientiousness & & Investigative \\
\hline & Investigative & & Conscientiousness \\
\hline \multirow[t]{6}{*}{ Least dominant } & Enterprising & Least valued & Realistic \\
\hline & Communication Realistic & & Structure \\
\hline & Artistic & & Analytical \\
\hline & & & Risk \\
\hline & & & Artistic \\
\hline & & & Social \\
\hline
\end{tabular}

Note characteristics of value in accountancy which were also held by accountancy students are in bold.

The characteristics of the students were compared with those valued in the profession (Table 4). It was found that the students exhibited some characteristics which are valued in accountancy such as conventional, conscientiousness and investigative characteristics. However, the students did not display strong communication skills and enterprising characteristics. These were among the most sought after characteristics of accountants. The possible reasons for this are discussed below. The students also had high scores in a preference for structure, risk and social characteristics. These were among the least important characteristics in the experts'opinion.

Table 5. Comparison of the characteristics and skills for specialisations

\begin{tabular}{lll}
\hline Specialisation & Student characteristic & Expert valued characteristic \\
\hline Audit & Less cautious approach to risk & Realistic \\
& & Investigative \\
& & Conventional \\
& & Conscientious \\
Forensic & Analytical & Investigative \\
& Conscientious (CIT) & Conventional \\
& & Conscientious \\
$\operatorname{Tax}$ & Investigative & Investigative \\
\hline
\end{tabular}




\begin{tabular}{lll}
\hline & & Conscientious \\
Enterprise & Realistic & $\mathrm{n} / \mathrm{a}$ \\
Financial advice & Less conventional & Enterprising \\
& Less preference for structure & Conventional \\
Consultancy & No statistically significant differences $\quad$ in & Investigative \\
& characteristics & Artistic \\
& & Enterprising \\
Family firm & Structure & Realistic \\
& & Enterprising \\
& & Conventional \\
\hline
\end{tabular}

Note characteristics of value for specialisations which were also held by students with a preference for the specialisation are in bold.

Experts specified which characteristics from the RIASEC dimensions and conscientiousness they valued for each specialisation. The characteristics of the students were found to vary depending on their specialisation preferences and were compared to the characteristics valued for each specialisation (Table 5). There was some overlap between student characteristics and expert opinion for forensic accountancy and tax specialisation. However, students did not typically exhibit the characteristics considered by the experts to be important for their preferred specialisations. Experts reached over $70 \%$ concurrence on the characteristics desirable for the specialisations with the exception of public accountancy. However, it is interesting to note that realistic and social characteristics were the most valued characteristics for this specialisation. Expert interviews informed the student survey and resulted in the addition of enterprise and large accountancy firm as specialisations subsequent to the interviews and so are not applicable for comparative purposes. No statistically significant differences in characteristics were found among students with a preferences for working in a large accountancy firm.

\section{Discussion}

This research proposes considerations to increase the likelihood of good person-job fit in accountancy. It identified characteristics and skills of importance in accountancy and its specialisations. Gaps between student characteristics and those needed for accountancy were identified in this research. A preference for structure, cautious approach to risk, conventional and social characteristics were dominant characteristics in the student sample. Experts considered communication skills and enterprising characteristics followed by conventional and investigative characteristics and conscientiousness to be important in accountancy. While students exhibit some of the characteristics valued in accountancy, skills gaps were especially evident in communication skills and enterprising characteristics. A number of factors are likely to contribute to the skills gap. It is possible that accountancy may not be attracting those with highly developed communication skills and enterprising characteristics due to the accountant stereotype. The accountant stereotype suggests that a beancounter-bookkeeper personality is required to be able to perform the duties of an accountant. This may result in bias against joining the accountancy profession. It may also result in attracting students with the characteristics of the stereotypical accountant. Another possibility is that there is a lack of appreciation among students of the skills necessary for a career in accountancy. Additionally, students may have a lack of appreciation of their own characteristics and this may partly explain the less than ideal person-job fit. Accounting education may bear some responsibility for the skills gap. Accounting education has traditionally focused on the teaching of technical skills. While some efforts have been made to bridge the skills gap, there is an opportunity for educators to aid the development of desirable skills to better equip students for the workplace. Educators may need to liaise with employers to ensure their courses focus on the skills needed. It is interesting to note that skills gaps were also found for the specialisations. Apart from forensic accountancy and tax, students did not exhibit the desired characteristics for their choice of specialisation.

\subsection{Theoretical Contribution}

This research expands Holland's (1959) RIASEC model as it applies to accountancy. The finding that the primary quality necessary for accountancy is communication skill followed by enterprising and conventional characteristics is noteworthy. This is an important development and represents a move away from the traditional view of accountants as being primarily conventional. It suggests that the pre-existing classifications may need to be reconsidered. It marks an acknowledgement of the evolution of the role and does not perpetuate the accountant stereotype. A new concept of the type of individual suited to the role has emerged. 


\subsection{Practical Contributions and Recommendations}

There are implications arising from this research for employers, students and educators. This research makes a valuable contribution to informing recruitment decisions for accountancy firms. Challenges in recruitment may be addressed through assessment of person-job fit based on applicant characteristics. This research provides employers with a definitive list of characteristics and skills which they may assess as part of the recruitment and selection process. This may involve the use of assessment centres and the hiring of professionals to oversee personality testing. Communication skills, in particular, need to be assessed prior to hiring accountants. Testing of these skills may be best achieved through appraising cover letters, organising comprehension testing and formally evaluating presentation skills at the interview stage. Sponsorship of essay writing and debating competitions at universities may also aid the identification of strong communicators. Likewise, firms may wish to identify students with strong enterprising characteristics through sponsorship of entrepreneurial competitions. They may increase the likelihood of attracting students with many of the desirable characteristics through careful image promotion, thereby avoiding the stereotypical accountant personality. These measures are likely to decrease turnover due to poor person-job fit. It is also a recommendation that employers invest in training existing employees in communication, leadership and mentoring skills.

Students may match their characteristics to specialisations through self-assessment of their characteristics using the questionnaire developed in this research. Consideration could then be given to the characteristics and skills identified as important for working in different areas of accountancy. Any skills gaps could be bridged prior to applying for employment.

In addition to providing students with information about the characteristics and skills needed for accountancy, educators may wish to address the skills shortfall of the students. The addition of communication skills training would be welcomed. Video technology use could be encouraged to provide accountancy students with insight regarding their presentation skills (Cameron \& Dickfos, 2013). Enterprising characteristics could also be developed. For example, leadership training similar to that offered by large accountancy firms (Bloch et al., 2012) may be offered. Innovation could be encouraged through entrepreneurial activities.

In terms of the specialisations, educators may wish to streamline skills development based on students' interest in different specialisations. For example, creativity training would benefit those interested in consultancy. Enterprising characteristics could be particularly encouraged in those interested in consultancy, financial advice or family firms. Additionally, accountancy bodies may wish to address the issue of the accountant stereotype as this may be a factor in terms of attracting those with highly developed communication skills and enterprising characteristics.

\section{Conclusions}

The findings of this research indicate that the qualities most valued for a career in accountancy are communication skills and enterprising characteristics. These are followed at some distance by conventional characteristics. This research also concluded that accountancy students tend to have a preference for structure, a cautious approach to risk and are conventional. It can be held that accountancy students today exhibit some of the characteristics of use in accountancy, particularly those characteristics less central to the role. However, communication skills and enterprising characteristics were found to be deficient. In general, students did not have the characteristics necessary for their preferred areas of specialisation. Exceptions were for forensic accountancy and tax.

Future research may consider management accountancy and other business courses. Through taking a similar approach to identifying the characteristics and skills necessary for different occupations, this research could be built upon to encourage good person-job fit in a range of professions. Pilot studies to determine whether the skills training suggested in this research is transferrable to the workplace would also be worthwhile.

\section{References}

Amabile, T. M., Hill, K. G., Hennessey, B. A., \& Tighe, E. M. (1994). The Work Preference Inventory: Assessing intrinsic and extrinsic motivational orientations. Journal of Personality and Social Psychology, 66(5), 950.

Anderson, N. R., \& West, M. A. (1998). Measuring climate for work group innovation: development and validation of the team climate inventory. Journal of Organizational Behavior, 235-258.

Bishop, D. (2017). Context, agency and professional workplace learning: trainee accountants in large and small practices. Education \& Training, 59(5). https://dx.doi.org/10.1108/ET-07-2016-0129

Bland, J. M., \& Altman, D. G. (1997). Statistics notes: Cronbach's alpha. Bmj, 314(7080), 572. 
Bloch, J., Brewer, P. C., \& Stout, D. E. (2012). Responding to the leadership needs of the accounting profession: A module for developing a leadership mindset in accounting students. Issues in Accounting Education, 27(2), 525-554. https://dx.doi.org/10.2308/iace-50125

Braun, V., \& Clarke, V. (2006). Using thematic analysis in psychology. Qualitative Research in Psychology, 3(2), 77-101. https://dx.doi.org/10.1191/1478088706qp063oa

Cameron, C., \& Dickfos, J. (2014). 'Lights, Camera, Action! 'Video Technology and Students' Perceptions of Oral Communication in Accounting Education. Accounting Education, 23(2), 135-154. https://dx.doi.org/10.1080/09639284.2013.847326

Chartered Accountants of Ireland (2016). Retrieved from https://www.charteredaccountants.ie/

Chen, C. C., Jones, K. T., Scarlata, A. N., \& Stone, D. N. (2012). Does the Holland model of occupational choice (HMOC) perpetuate the Beancounter-Bookkeeper (BB) stereotype of accountants? Critical Perspectives on Accounting, 23(4), 370-389. https://dx.doi.org/10.1016/j.cpa.2011.10.006

Cleary, M., Horsfall, J., \& Hayter, M. (2014). Data collection and sampling in qualitative research: does size matter? Journal of Advanced Nursing, 70(3), 473-475.

Cohen, J. (1988). Statistical power analysis for the behavioral sciences Lawrence Earlbaum Associates. Hillsdale, $N J, 20-26$

Crawford, L., Helliar, C., \& Monk, E. A. (2011). Generic skills in audit education. Accounting Education: an International Journal, 20(2), 115-131. https://dx.doi.org/10.1080/09639284.2011.557487

Downey, R. G., \& King, C. V. (1998). Missing data in Likert ratings: A comparison of replacement methods. The Journal of General Psychology, 125(2), 175-191.

Gottfredson, G. D., \& Holland, J. L. (1996). Dictionary of Holland occupational codes. Psychological Assessment Resources Inc.

Gupta, S., \& Marshall, L. L. (2010). Congruence between entry-level accountants' required competencies and accounting textbooks. Academy of Educational Leadership Journal, 14(1), 1.

Helliar, C. V., Lonie, A. A., Power, D. M., \& Sinclair, C. D. (2002). Managerial attitudes to risk: a comparison of Scottish chartered accountants and UK managers. Journal of International Accounting, Auditing and Taxation, 11(2), 165-190.

Holland, J. L. (1959). A theory of vocational choice. Journal of Counselling Psychology, 6(1), 35.

Holland, J. L. (1973). Making vocational choices: A theory of careers. Prentice Hall.

Holland, J. L., \& Baird, L. L. (1968). An interpersonal competency scale. Educational and Psychological Measurement, 28(2), 503-510.

International Item Personality Pool (2017). Retrieved from http://ipip.ori.org/

Jackling, B., \& De Lange, P. (2009). Do accounting graduates' skills meet the expectations of employers? A matter of convergence or divergence. Accounting Education: an International Journal, 18(4-5), 369-385. https://dx.doi.org/10.1080/09639280902719341

Jackling, B., \& Watty, K. (2010). The accounting professional of the future: never mind the quality check the look! International Journal of Critical Accounting, 2(2), 170-190.

Kavanagh, M. H., \& Drennan, L. (2008). What skills and attributes does an accounting graduate need? Evidence from student perceptions and employer expectations. Accounting \& Finance, 48(2), 279-300. https://dx.doi.org/10.1111/j.1467-629x.2007.00245.x

Lawson, R. A., Blocher, E. J., Brewer, P. C., Morris, J. T., Stocks, K. D., Sorensen, J. E., Stout, D.E. \& Wouters, M. J. (2015). Thoughts on competency integration in accounting education. Issues in Accounting Education, 30(3), 149-171. https://dx.doi.org/10.2308/iace-51021

Levy, J. J., Richardson, J. D., Lounsbury, J. W., Stewart, D., Gibson, L. W., \& Drost, A. W. (2011). Personality Traits and Career Satisfaction of Accounting Professionals. Individual Differences Research, 9(4).

Meertens, R. M., \& Lion, R. (2008). Measuring an individual's tendency to take risks: The risk propensity scale. Journal of Applied Social Psychology, 38(6), 1506-1520.

Pholphirul, P. (2017). Educational mismatches and labor market outcomes: Evidence from both vertical and horizontal mismatches in Thailand. Education \& Training, 59(5), 534-546. 
https://dx.doi.org/10.1108/ET-11-2016-0173

Sandelowski, M. (2000). Focus on research methods combining qualitative and quantitative sampling, data collection, and analysis techniques. Research in Nursing \& Health, 23(3), 246-255.

Silva, J. P., Portela, F., Santos, M. F., \& Taveira, M. D. C. (2014). Intelligent Decision Support for University application using RIASEC codes. In Proceedings of the 8th International Technology, Education and Development Conference (INTED 2014) 7231-7241.

Siriwardane, H. P., Hu, B., \& Low, K. Y. (2014). Skills, Knowledge, and Attitudes Important for Present-Day Auditors. International Journal of Auditing, 18(3), 193-205. https://dx.doi.org/10.1111/ijau.12023

Tuckett, A. G. (2005). Applying thematic analysis theory to practice: a researcher's experience. Contemporary Nurse, 19(1-2), 75-87.

\section{Copyrights}

Copyright for this article is retained by the author(s), with first publication rights granted to the journal.

This is an open-access article distributed under the terms and conditions of the Creative Commons Attribution license (http://creativecommons.org/licenses/by/4.0/). 